\title{
Kielen materiaalinen toiminta Raisa Marjamäen runoteoksessa Ei kenenkään laituri
}

Raisa Marjamäen runoteoksen Ei kenenkään laituri (2014) ensimmäiselle sivulle on painettu kaksi lyhyttä, itsenäisenä kokonaisuutena hahmottuvaa tekstifragmenttia. Näistä jälkimmäinen, aivan sivun alalaitaan asemoitu yksirivinen teksti muotoutuu kokonaisuudessaan seuraavasti:

kielo talvehtii piiloutuneena kieltoon

(Ei kenenkä̈̈n laituri, $\mathrm{i} / \mathrm{I}^{1}$; tästä eteenpäin EKL.)

Syntaktisesti suorasukainen tekstirivi mieltyy alkuosaltaan kuin jatkuvaa tai pitkäkestoista, prosessuaalista asiantilaa kuvaavana väitelauseena: juurakkonsa avulla talvehtiva kielokasvi piiloutuu maan alle talven ajaksi. Rivin viimeinen sana 'kieltoon' sopii kuitenkin kehnosti tekstiä asiantilan kuvauksena tarkastelevaan tulkinnalliseen kehikkoon, lauseen ilmaisemassa väitteessä kun ei tunnu kokonaisuutena olevan oikein mitään järkeä. Rivin päättävä sana hajauttaa lauseen semanttista kenttää kääntäen ilmaisun fokuksen sivuun tekstin aihetason elementeistä. Nelisanainen, semanttisesti epäkoherentti tekstirivi tuntuu näin asiantilan esittämisen sijaan ilmaisevan ennemminkin kielen epäonnistumista representatiivisessa ${ }^{2}$ tehtävässään.

Marjamäen teos hahmottuu jo yksinomaan kirjan käyttöliittymän - kirjaesineen materiaalisen, lukijan havaintoa ja lukukokemusta ohjaavan, käsin kosketeltavan rakenteen - näkökulmasta poikkeuksellisena julkaisuna. Teoksen sivuja ei ole sidottu yhtenäiseen koodeksimuotoon, vaan kokonaisuus pysyy kasassa - ja suljettuna - kirjan ympärille venytettävien leveiden kuminauhojen avulla. Samalla kokoelman symmetrisenä hahmottuva sikermäjärjestys kumpuaa kirjaesineen materiaalisista ominaisuuksista: kukin sikermä rakentuu kahdesta irtonaisesta, sisäkkäin kahdeksansivuiseksi lehtiseksi taitellusta A4-arkista. Teoksen takakansitietojen mukaan kirja on lisäksi vallitsevista digitaalisista painokäytänteistä poiketen irtokirjakkeista käsin ladottu ja kohopainokoneella painettu.

Tekstirivin "kielo talvehtii piiloutuneena kieltoon" semanttinen ja representatiivinen epävakaus ohjaa, yhdessä kirjaesineen materiaalisesti kohosteisen erityislaadun kanssa, lukijaa kiinnittämään huomion kieleen itseensä; siihen, mitä tekstissä paperille 
painettujen kirjainten ja sanojen tasolla lukemistilanteen edetessä tapahtuu. Marjamäen ilmaisussa korostuu näin painetun kielen luonne ulottuvaisiksi, ruumiillisiksi kirjain- ja sanahahmoiksi sekä näiden välisiksi relaatioiksi järjestyvänä materiaalisena entiteettinä. Tekstissä aktualisoituu erilaisia aineellisina hahmottuvia suhteita ja vaikutuksia, jotka eivät tyhjene sanojen semanttisen merkityksen piiriin.

Painettu kieli hahmottuu kirjan sivulla materiaalisesti latautuneena alueena, kirjainmerkkien ja sanoiksi koostuneiden kirjainmerkkijoukkojen välisinä jännitteinä, korostumisina, yhteentakertumisina ja eroina; tekstin materiaalisena intensiteettinä. Ranskalainen filosofi Gilles Deleuze, jonka ajattelusta kumpuaviin käsitteellistyksiin tukeudun tässä artikkelissa monin paikoin, määrittelee intensiteetin eroavuudeksi. Deleuzen filosofiassa kaiken ilmenemisen ja tapahtumisen ytimessä on eron intensiivisyys; ero ei ole binaarista, negatiivista eroamista jostakin, vaan ennemminkin intensiivistä, positiivista ja puhdasta eroa, eroa itsessään. Intensiteetti on eron aistein havaittava muoto. (Deleuze 1994, 222.) ${ }^{3}$ Näin käsitteellistettynä (runo)kielen materiaalinen intensiteetti hahmottuu tekstissä eri tavoin ilmeneviksi - erilaisiin intensiivisiin muotoihin aineellistuviksi - eroiksi kielen materiaalisessa perustassa.

\section{Intensiiviset sanaruumiskoosteet}

Kysymys tekstilajista nousee toistuvasti esille Marjamäen teoksen lukutapahtuman yhteydessä. Yleisten kirjastojen luokitusjärjestelmän puitteissa Ei kenenkään laituri on kirjan takakannen merkinnän perusteella määritelty yksiselitteisesti (suomenkieliseksi) runoudeksi (kirjastoluokka 82.2). Kokoelman monihahmotteinen muotokieli itsessään tuntuu kuitenkin kyseenalaistavan runouden ja sen lähilajien - erityisesti aforismin, fragmentin ja epigrammin - väliset selkeät rajanvedot. ${ }^{4}$ Teos rikkoo runoilmaisun rakenteellisia lajikonventioita toistuvasti myös jakamalla sivutilan useamman tekstin kesken: Marjamäen kokoelmassa yksittäiselle sivulle on painettu vaihtelevasti joko yksi tai kaksi itsenäisenä hahmottuvaa tekstiä. Nämä tekstit on asemoitu sivujen ylä- ja/tai alareunoihin siten, että sivun keskelle jää alati runsaasti lukukokemusta rytmittävää, tekstejä toisistaan erottavaa tyhjää paperitilaa. Ilmaisun muotokielen painotukset vaihtelevat teoksessa kautta linjan epäsännöllisellä frekvenssillä. Vaikutelma tekstilajin epämääräisyydestä onkin kokoelman lukukokemusta voimakkaasti määrittävä elementti.

Marjamäen teoksen tekstit hahmottuvat kirjan sivuilla kielen materiaalista intensiteettiä painottavana runoilmaisuna. Runokielen materiaalisuudella tarkoitetaan kirjallisuudentutkimuksessa kirjoituksen aineellisia tai aineellisiksi koettuja ominaisuuksia: runon sanojen, lauseiden ja syntaksin vaikutuksia sekä sitä, miltä teksti näyttää paperilla ja kuulostaa lausuttuna (ks. Kainulainen 2011, 14; Kainulainen, Lummaa \& Seutu 2012, 9-10; Lappalainen 2012, 40; vrt. myös Joensuu 2012, 30-34). Tällaisissa määritelmällisissä kehyksissä itse runous on mielletty toiminnaksi, jonka puitteissa runokie- 
len materiaalisuutta voidaan tutkia (ks. Kainulainen 2011, 13). Aluksi siteeraamassani Marjamäen kokoelman yksirivisessä tekstissä kielen materiaalisuus ei hahmotukaan ensisijaisesti ilmaisun merkityssisältöä tukevana tai kontrastoivana tasona, vaan teksti mieltyy kokonaisuudessaan ennemminkin kielen materiaalisuutta tutkivaksi toiminnaksi. ${ }^{5}$

Olen valikoinut analyysikohteeni Marjamäen teoksen monilajisesta tekstijoukosta paitsi niiden kielen painettuun, materiaaliseen luonteeseen palautuvan kohosteisuuden, myös tekstien relationaalisen suppeuden perusteella. Artikkelimuodon sallimissa rajoissa olisikin ollut mahdotonta eritellä yksityiskohtaisesti kokoelman laajempien tekstien materiaalisia ominaisuuksia. Näkökulmani painottaa lisäksi Marjamäen teoksen ilmaisullista heterogeenisyyttä; tekstiesimerkit eivät toisin sanoen niinkään edusta teoskokonaisuutta, vaan hahmottuvat ennemminkin partikulaarisina, kokoelman runoilmaisun materiaalista intensiivisyyttä aktualisoivina teksteinä. Koska artikkelini fokus on ilmaisun tekstilajin määrittämisen sijaan kirjoituksen aineellisten ominaisuuksien tarkastelussa, viittaan analyysikohteisiini, asiayhteydestä riippuen, käsitteillä teksti ja tekstirivi. Teoksen kirjastoluokituksen perusteella miellän Marjamäen kokoelman ilmaisukeinojen paikantuvan kuitenkin ensisijaisesti lyriikan alueelle. Näin ollen käytän ajoittain myös termejä runokieli ja runoilmaisu viitatessani yleisemmällä tasolla teoksen ilmaisullisiin ratkaisuihin.

Kielen materiaalisuuden yhteyteen on liitetty käsitys sanan ruumiillisuudesta, sanasta ruumillisena oliona (ks. esim. Kainulainen 2011, 14; Huth 2010; vrt. myös Katajamäki 2004, 143-144). Paperille painetulla sanalla on materiaalinen ruumis, konkreettiset painovärin ja paperin raameissa hahmottuvat aineelliset rajansa. Sana toisin sanoen ruumiillistuu tullessaan painetuksi paperille (vrt. Huth 2010). Hahmotan analyysissani sanan ruumiillistumisen Gilles Deleuzen ruumiin käsitettä soveltaen. Deleuze käsitteellistää ruumiin materiaalisesti ulottuvaiseksi, inhimilliseksi tai ei-inhimilliseksi, osiensa välisten relaatioiden määrittämäksi kokonaisuudeksi. Ruumis on ontologisesti tarkasteltuna intensiivistä todellisuutta, ruumiin muodostavien osien välisiin suhteisiin palautuvaa materiaalista eroa. Keskeinen ruumista määrittävä ominaisuus on sen kyky affektiiviseen - vaikuttavaan ja vaikuttuvaan - vuorovaikutukseen toisten ruumiiden kanssa. (Baugh 2010, 35-37.) Sanan ruumiillistuminen mieltyy näin käsitteellistettynä kirjoitusmerkkien välisessä vuorovaikutuksessa aktualisoituvaksi materiaaliseksi intensiteetiksi; sanaruumis on jo itsessään, relationaalisena kokonaisuutena, intensiivinen ja eroava entiteetti.

Yksi sanan ruumiillisuuteen ja kielen materiaaliseen intensiteetiin keskittyvän artikkelini motiiveista on luonnostella esille uudenlaista, uusmaterialistiseksi käsitteellistyvää metodista tulokulmaa lyriikan analyysiin. Uusmaterialismilla tarkoitetaan maailmaa ensisijaisesti materiaalisten prosessien näkökulmasta tarkastelevaa filosofiaa ja teorianmuodostusta. Diane Coole ja Samantha Frost (2010, 2-3) määrittelevät uusmaterialis- 
min kulttuurisen käänteen jälkeen uudelleen virinneeksi teoreettiseksi kiinnostukseksi maailman materiaalista todellisuutta kohtaan. Uusmaterialismi tarkastelee materian merkitystä (significance) sekä sitä, miten materiaa ylipäänsä tulisi teoreettisesti lähestyä. Yksi uusmaterialistisen analyysin keskeisistä kohteista on Coolen ja Frostin (2010, 3-4) mukaan ihmisen jokapäiväinen vuorovaikutus materiaalisten objektien ja luonnollisen ympäristönsä kanssa. Milla Tiainen ja Jussi Parikka (2010) taas hahmottavat uusmaterialismin materian aktiivisuuden, muotoumisen ja affektiivisuuden kysymyksiä käsitteleväksi teoreettiseksi virtaukseksi. Rakennan analyysini näiden edellä mainittujen käsitteellistysten varaan. Sen sijaan, että kysyisin tarkastelemieni tekstien merkitystä, kysyn sitä, miten tekstit paperille painettuina materiaalisina oliona toimivat; millaisten sisäisten suhteiden ja aineellisten prosessien varassa tekstit operoivat, ja millaisia vaikutuksia runot kykenevät näin tuottamaan (vrt. Baugh 2000, 35-36). ${ }^{6}$

Uusmaterialistisesta näkökulmasta käsin Marjamäen kokoelman tekstit hahmottuvat sanaruumiillisista olioista rakentuvina materiaalisina koosteina. Uusmaterialistifilosofi Manuel DeLanda (2006, 10) määrittelee koosteen autonomisista komponenteista muodostuvaksi ja näiden komponenttien välisten ulkoisten relaatioiden varaan rakentuvaksi kokonaisuudeksi. Komponentin roolia koosteessa määrittää yhtälllä se, vakauttaako vai hajauttaako komponentti koosteen homogeenisuutta ja identiteettiä, ja toisaalta taas se, millaisen roolin komponentti saa koosteessa akselilla materiaalinenilmaiseva (DeLanda 2006, 11).

Tältä pohjalta jäsennän omaa luentaani tarkastelemalla Marjamäen tekstejä - intensiivisiä sanaruumiskoosteita - materiaalisuuden ja ilmaisevuuden jännevälillä aktualisoituvana liikkeenä. Claire Colebrook $(2010,96)$ käsitteellistää (tekstin) ilmaisevuuden sanojen välisten uusien kytköksten ja jännitteiden potentiaaliksi. Sanaruumiskoosteeksi mielletyn tekstin ilmaisevuus tarkoittaa kuitenkin eri asiaa kuin sen muodostavien komponenttien semanttinen merkitys. Ilmaisevuus voi olla myös yksinomaan koosteen tai sen komponentin materiaalisiin ominaisuuksiin palautuvaa. ${ }^{7}$ Artikkelini painopiste on juuri näiden koosteen komponenttien materiaalisten piirteiden ja relaatioiden tarkastelussa. Huomioin analyysissani kuitenkin myös sanaruumiiden semanttisen tason, milloin se kytkeytyy olennaisesti tekstin materiaalisen toiminnan ja ilmaisevuuden kysymyksiin.

\section{Tulemisen kerrostumia}

Ei kenenkään laituri -kokoelman teksteissä sanaruumiiden sisäinen, kirjoitusmerkkien välisiin relaatioihin paikantuva intensiivisyys ilmenee tavalla, joka tekee kielen, kirjoituksen ja kirjallisuuden tuottamisen prosessit näkyviksi teksteissä (vrt. Hertzberg 2002, 28-29). Irtokirjakkeista ladotun, kohopainotekniikalla toteutetun teoksen painojälki on huomattavan epäyhtenäistä. Painoväri on levittynyt niin tekstien kuin yksittäisten 
sanaruumiidenkin sisällä epätasaisesti. ${ }^{8}$ Tekstiin syntyy näin kirjan tuotantoprosessiin palautuvaa aineellista kohosteisuutta, ilmaisevuutta, joka ei palaudu kielen semanttisen merkityssisällön piiriin. Käyttämässäni teoskappaleessa esimerkiksi ylle lainatulla tekstirivillä "kielo talvehtii piiloutuneena kieltoon" 'kielo'-sanan $o$-, 'talvehtii'-sanan $a$ - ja jälkimmäinen $i$-, sekä 'kieltoon' -sanan $l$ - ja ensimmäinen $o$-kirjain hahmottuvat rivin muita kirjoitusmerkkejä tummempina, intensiivisempinä grafeemeina.

Epätasainen painojälki toimii teoksessa osaltaan kirjan kirjoitus-, ladonta- ja painoprosessien työläyttä ilmaisevana aineellisena ominaisuutena. Painoväri on tarttunut paperiin vaihtelevalla tiheydellä, kuin kehnolaatuisella kuulakärkikynällä käsin kirjoittaessa, ja lopputulos ilmenee lukijalle painetun kielen materiaaliseen intensiteettiin palautuvana vaikutuksena. Ilmaisun aineellinen kohosteisuus kytkee kokoelman tekstit samalla (sana)ruumiillisesti osaksi tekstin ulkopuolisia institutionaalisia käytänteitä. Marjamäen tekstit eivät hahmotu niinkään autonomisina, sisäisen esteettisen todellisuutensa varassa operoivina taide-esineinä, kuin erottamattomana osana niitä materiaalisia prosesseja, joiden puitteissa kirjallisuutta tuotetaan ja välitetään.

Sanaruumiiden välisen vuorovaikutuksen näkökulmasta yksi tekstirivin "kielo talvehtii piiloutuneena kieltoon" keskeisistä materiaalisista ominaisuuksista on sanojen 'kielo' ja 'kieltoon' grafeemisella ja näönvaraisella tasolla ilmenevä samankaltaisuus. Semanttisesti sanojen välille ei sen sijaan tunnu kehittyvän tekstikokonaisuuden puitteissa mielekästä yhteyttä, päin vastoin: juuri runon päättävä sana 'kieltoon' rikkoo ja hajauttaa yksirivisen tekstin semanttista koherenssia. Kielitieteessä kielto määritellään muodoksi, joka ilmaisee, että jokin asiantila tai ominaisuus ei päde (Tieteen termipankki: Kielitiede:kielto). Syntaktisesti ja semanttisesti tarkasteltuna Marjamäen teksti rakentuukin paradoksaalisen kielellisen tilanteen ympärille: semanttisesti tekstirivillä ilmaistu tapahtuva asiantila, kielokasvin piiloutuminen ja talvehtiminen, kirjoittuu tekstin edetessä osaksi negaation, koko esitetyn asiantilan pätemättömyyden, ilmausta.

Ilmaisun semanttinen ja syntaktinen ristiriitaisuus korostuu sanojen ruumiillisiin ominaisuuksiin kirjan sivulla palautuvan relationaalisen vaikutuksen muodossa. Tekstirivillä aktualisoituu intensiivinen, eroa ilmentävä materiaalinen jännite sanaruumiiden ‘kielo’ ja ‘kieltoon’ välillä. Sana ‘kielo’ vaikuttaa sanaan 'kieltoon' paitsi sanaolioiden grafeemisen, visuaalisena yhdenmukaisuutena hahmottuvan ruumiillisen samankaltaisuuden, myös sanaruumiiden sisäisen, yksittäisten kirjoitusmerkkien tasolle paikantuvan materiaalisen intensiteetin muodossa. Sanan 'kielo' päättävä o-kirjain ja ‘kieltoon' -sanan ensimmäinen $o$-kirjain ilmenevät paperilla sanojen muita kirjainmerkkejä tiheämpinä grafeemeina, vieläpä niin, että 'kieltoon' -sanan $o$-kirjain hahmottuu näistä kahdesta tummempana, paksumman viivan varaan piirtyvänä kirjainmerkkinä. Sanaruumis 'kielo' ilmenee sanaruumiissa 'kieltoon' näin jo aineellisesti, painovärin kerrostuneena läsnäolona. Samalla sana 'kieltoon' vaikuttaa relationaalisessa intensiivisyydessään häirit- 
sevästi sanaruumiin 'kielo' representatiiviseen, sanan semanttiseen merkitykseen palautuvaan ilmaisuvoimaan. Grafeemikooste 'kielo’ muuntuu näin tekstirivin relationaalisessa vaikutuskentässä referentiaalisesta, kasviin viittaavasta merkitsijästä aineelliseksi, semanttiselta sisältöarvoltaan alentuneeksi tai häiriintyneeksi, mutta samalla materiaalisesti intensifioituvaksi sanaruumiiksi. Sanaruumis 'kielo' kerrostuu - kirjaimellisesti "piiloutuu" - tekstin painojäljen intensiivisyytenä sanaruumiiseen 'kieltoon'. Rivin viimeinen sana kääntää tekstin fokuksen näin asiantilan esityksestä kielen aineellisiin rakenteisiin kiinni tarrautuvaksi ja näitä rakenteita painojäljen intensiivisyyden avulla tutkivaksi ilmaisuksi.

Ymmärrän Marjamäen tekstin toiminnassa olevan pohjimmiltaan kysymys sanan ruumiillisesta metamorfoosista, kahden tai useamman sanaruumiin välisessä vuorovaikutuksessa aktualisoituvasta materiaalisesta muutoksesta. Tekstirivin aineellisesti intensiivinen dynamiikka aktualisoi näin Gilles Deleuzen filosofiassa keskeistä tulemisen prosessia. Cliff Stagoll $(2010,26)$ tiivistää tulemisen käsitteen eron jatkuvaksi tuottumiseksi tapahtumien immanentissa perustassa; tuleminen ei ole niinkään muutoksen lopputulos kuin muutoksen dynamiikkaa, tapahtumista. Marjamäen tekstissä sanaruumis 'kielo' tulee paitsi materiaalisesti, intensiivisen painojäljen tasolla, myös syntaktisen liikkeen kautta sanaruumiiseen 'kieltoon'. 'Kielo’ piiloutuu 'kieltoon' ruumiillisesti läsnä olevana, mutta samalla jo toiseksi muuttuneena, intensiivisenä ja eroavana materiaalisena kerrostumana. Painojäljeltään epätasaisessa tekstissä aktualisoituva sanaruumiin intensiivinen metamorfoosi materialisoi näin runokielessä avautuvaa muutoksen potentiaalia. Kieli hahmottuu Marjamäen tekstissä avoimuutena ja mahdollisuutena, vakiintuneista ja staattisista rakenteista - esimerkiksi runoilmaisun representatiivisten funktioiden ja sanojen semanttisten merkitysten ensisijaisuudesta - irtautuvana liikkeenä kohti uutta ja ennenkokematonta (vrt. Connolly 2011, 9).

\section{Grafeemien materiaaliset aukileet}

Ei kenenkään laituri -kokoelman tekstien materiaalinen ilmaisevuus ei rajoitu yksinomaan painovärin, kirjoitusmerkkien ja sanaruumiiden tasolla aktualisoituvaksi ilmiöksi. Kirjan sivuilla runsaana ilmenevä tyhjä paperitila intensifioituu sekin teoksessa eri tavoin. Sanaruumiskoosteen sisäiset, painoväristä tyhät alueet jännitteistyvät ilmaisullista painoarvoa omaaviksi kentiksi esimerkiksi tällä, kokoelman keskivaiheilta löytyvällä tekstirivillä:

\section{aukile, luutumaton maatumaton kohta kallossa}

$(\mathrm{EKL}, \mathrm{v} / \mathrm{V}$. 
Kuten edellä tarkastellussa kielo-esimerkissä, vaikuttaa tässäkin tekstissä olevan ensilukemalta kyse verrattain suorasukaisesta asian tai asiantilan esityksestä. Painetun kielen aineellisina hahmottuvat ominaisuudet häiritsevät kuitenkin myös tämän tekstirivin mieltämistä ensisijaisesti representatiivisena ilmaisuna. Samalla kielen immanentin, materiaalisen toiminnan mekanismit poikkeavat näiden kahden tekstin kohdalla toisistaan merkittävissä määrin.

Semanttisella tasolla ylle lainattu teksti ilmaisee sikiön tai pienen lapsen kehitysvaihetta, jossa osa kallosta ei ole vielä luutunut umpeen. Aukile viittaa anatomian alaan kuuluvana sanana (ei-)orgaanisen materian rajaamaan, etenevän luutumisen myötä alati supistuvaan ja lopulta kokonaan katoavaan tyhjään tilaan; toisin sanoen johonkin sellaiseen, jonka ei autonomisena, aineellisena entiteettinä voi katsoa oikeastaan olevan edes olemassa. Teksti ilmaisee semanttisella tasolla näin partikulaarista materiaalista prosessia, aukileen katoamiseen lopulta johtavaa (umpeen)luutumisen tapahtumaa.

Myös aukile-tekstin materiaalinen toiminta fokusoituu kahden sanaruumiin välisen metamorfisen tulemisen prosessin ympärille. Vierekkäisten grafeemikoosteiden 'luutumaton' ja 'maatumaton' morfologinen yhdenmukaisuus luo tekstiriville tautologisen tihentymän, jossa sanaruumis 'luutumaton' liukuu ja muuntuu - tulee - tekstin intensiivisessä painojäljessä materialisoituvan eron tuottumisen myötä sanaruumiiseen 'maatumaton'. Tautologinen rakenne korostaa samalla tekstikokonaisuutta aineettomuutta tai suoranaista tyhjyyttä ilmaisevana kielenä; vaikka teksti kokonaisuutena tarkasteltuna ilmentää luutumisen aineellista prosessia, kielletään tekstirivin syntaktisen aukile-subjektin oma oliollinen materiaalisuus tekstin semanttisella tasolla kaksinkertaisesti, luutumattomuuden ja maatumattomuuden attribuuttien välityksellä.

Kielen semanttisella tasolla ilmenevä tyhjyyden tai aineettomuuden ilmaisu hahmottuu tekstirivillä jännitteisenä suhteessa painetun kielen materiaalisiin ominaisuuksiin paikantuvaan ilmaisevuuteen. Toisiinsa metamorfisesti kytkeytyvistä sanaruumiista muodostuva tihentymä 'luutumaton maatumaton' synnyttää aineellista kohosteisuutta keskelle tekstirivin representatiivista tyhjyyttä. Samalla rivin ensimmäinen sana 'aukile' operoi tekstin sisäisen materiaalisen toiminnan puitteissa sanaruumiiden näönvaraisina hahmottuvia, sanojen grafeemiseen rakenteeseen palautuvia ominaisuuksia aktivoivana agenttina. Sanaruumiin 'aukile' semanttinen vaikutus intensifioi tekstissä runsaslukuisina esiintyvien, visuaalisesti aukilemaisina mieltyvien - painoväriaineksen rajaaman tyhjän tilan varaan rakentuvien $-a$ - ja $o$-kirjainten materiaalisia hahmoja. ${ }^{9}$ Tekstin syntaktinen subjekti, sana 'aukile', toimii sanaruumiskoosteessa näin materiaalisena, koko tekstikokonaisuutta aineellisesti intensiiviseen suuntaan liikuttavana komponenttina.

Tekstin painojäljen epätasaisuus ilmaisee aukilemaisten grafeemien intensiivisissä muodo(i)ssa luutumisen alati etenevää prosessia. Painovärin intensiteetti tihenee tekstirivin loppua kohti niin, että rivin viimeisen $a$-kirjaimen sisään jäävä tyhjä aukilemainen 
tila on jo huomattavasti suppeampi kuin rivin ensimmäisen a-kirjaimen vastaava. Tekstirivillä kielen aineellisten ominaisuuksien välityksellä ilmaistu luutumisen prosessi jää kuitenkin kesken, avoimeksi. Teksti ei sulkeudu esimerkiksi lauseen päättävän pisteen materiaaliseen, painoväristä umpeutuneeseen tihentymään, vaan rivin viimeinen kirjoitusmerkki on avonaisen, yhäti aukilemaisena mieltyvän tyhjän paperikentän ympärille levittäytynyt $a$-grafeemi.

Aukilemaisten $a$ - ja $o$-kirjainten sisälle jäävät tyhjät tilat hahmottuvat kirjan sivulla konkreettisina, lukijan katseen sisäänsä imaisevina aineellisina aukkoina, kohti uutta suuntaavina tulemisen alueina. ${ }^{10}$ Grafeemiaukileet materialisoituvat kirjan sivulle näin representaation transs(endenss)ista ulos johtavina pakoviivoina; ${ }^{11}$ tekstin $a$ - ja $o$-kirjainten materiaalisissa aukoissa aktualisoituva pakoviivojen liike mieltyy syvyyssuuntaisena, paperille painetun kielen materiaalisen pinnan läpäisevänä ja kohti seuraavalla aukeamalla sivun läpi jo himmeästi kuultavia uusia runoja suuntautuvana.

\section{Intensifioituva tyhjyys}

Kielen materiaalinen kohosteisuus ilmenee aukile-tekstissä paitsi grafeemit aktualisoivan painojäljen aineellisena intensiivisyytenä myös kirjoitusmerkkien sisälle rajautuvien, painoväristä tyhjien paperikenttien jännitteistymisenä. Aivan Marjamäen kokoelman alkupuolelta taas löytyy teksti, jossa runokielen aineellinen intensiteetti aktivoi ja jännitteistää myös sanaruumiskoosteen grafeemisten ääriviivojen ulkopuolista aluetta, tyhjää sivutilaa.

Teoskokonaisuuden avaavan sikermän keskiaukeamalle, sisäkkäin taiteltujen paperiarkkien materiaaliseen ytimeen, on painettu seuraava kaksirivinen teksti:

\section{Kukkikoon,}

Kukkikoon tukkoon.

(EKL, i/I.)

Muutoin tyhjänä ilmenevän aukeaman oikeanpuoleisen sivun alareunaan asemoitu sanaruumiskooste operoi koodeksiformaatin lukukäytänteiden varassa. Vasemmalta oikealle ja ylhäältä alas sivu kerrallaan etenevään kaunokirjalliseen ilmaisuun tottuneelle silmälle asemoinnin konventioita rikkova teksti tulee enemmän tai vähemmän yllätyksenä. Sivun esiin kääntävän lukijan silmä osuukin ensin herkästi tyhjään etsiytyessään automaattisesti aukeaman vasemmanpuoleisen sivun ylälaitaan.

Sikermän keskiaukeaman ainoa teksti ilmenee näin ensikatsomalta kuin välähdyksenomaisena, vain vaivoin havaintokynnyksen ylittävänä aineellisen intensiteetin alueena paperin valkoisen tyhjyyden, ja samalla lukijan näkökentän, rajamailla. Lukijan aukeaman vasemmanpuoleisen sivun ylälaitaan kiinnittynyt katse joutuu harhaile- 
maan tovin paperin kuituisen pinnan hahmottomassa tyhjyydessä etsiytyessään kohti näkökentän rajoilla sumeana tahrana häivähtävää, paperipinnan tasaisen intensiteetin muutoksena ilmenevää aluetta. Muilta osin tyhjä aukeama ei tarjoa katseelle kuitenkaan minkäänlaisia suuntaviivoja, joita pitkin edetä kohti aukeaman reunalla hahmottuvaa tekstialuetta. Lukijan katseelle avautuukin käytännössä rajaton määrä mahdollisia kulkureittejä, pakoviivoja, tekstin luokse. Tekstiä ympäröivä kirjoituksesta tyhjä kenttä on konkreettinen lukijan ja runokielen välillä aktualisoituva ja vaikuttava tulemisen tila, suuntaamatonta ja kahlitsematonta liikettä kohti katseen ja aineellisen tekstin välistä kytkeytymistä.

Tämä tulemisen liike jatkuu kolmisanaisen tekstikokonaisuuden sisällä sanaruumiiden intensiivisenä muodonmuutoksena. Sanan ruumiillinen metamorfoosi materialisoituu jo runon kahden ensimmäisen, niin grafeemisesti kuin semanttisellakin tasolla identtisenä hahmottuvan 'Kukkikoon' -sanan välisessä relaatiossa. Ainoa sanaruumiita erottava elementti on väli(lyönni)ttömästi tekstin avaavaa 'Kukkikoon'-sanaa seuraava, ja siten itse sanaruumiin autonomiseksi komponentiksi mieltyvä piste. Grafeemisella ja semanttisella tasolla identtiset sanat eroavat toisistaan näin sanaruumiiden materiaalisen, kirjain- ja välimerkkien välisiin relaatioihin palautuvan rakenteen tasolla. Tämä materiaalinen ero mieltyy Marjamäen tekstissä ilmaisevana ominaisuutena. Koosteen avaava, pisteeseen päättyvä 'Kukkikoon.'-sanaruumis hahmottuu tekstikokonaisuuden relationaalisissa puitteissa suljettuna ja staattisena yksikkönä siinä, missä koosteen toiselle riville painettu sanaruumis 'Kukkikoon' elehtii avoimesti eteen päin, kohti 'tukkoon'-sanan kanssa tapahtuvaa syntaktista kytkeytymistä.

Koosteen kaksi 'Kukkikoon' -sanaa poikkeavat toisistaan myös tekstin intensiivisessä painojäljessä materialisoituvien relationaalisten erojen tasolla. Esimerkiksi sanojen $i$-kirjaimissa ja $o$-kaksoisvokaaleissa ilmenee painojäljen tiheyteen, grafeemin muodostavan viivan paksuuteen, paikantuvaa variaatiota. Painoväri saa näin tässäkin koosteessa paitsi sanat paperille ruumiillistavan ilmaisuvälineen myös sanojen sisällä vaikuttavan intensiivisen, eroa tuottavan voiman roolin. Samalla koosteen jälkimmäisen tekstirivin muodostavien sanaruumiiden 'Kukkikoon' ja 'tukkoon.' välinen suhde mieltyy painojäljen intensiivisyyden puitteissa metamorfisena, tulemisen prosessin määrittämänä. 'Kukkikoon' tulee sanaan 'tukkoon' $u$-, $k$ - ja $o$-kirjainten painovärin kerrostumisina, sanaruumiiden välille metamorfisen relaation aiheuttavina siirtyminä. Niin kaksoiskonsonanttien ja -vokaalien $(k k, o o)$ kuin yksittäisten kirjoitusmerkkienkin $(K, u, n)$ toisteisuutena ilmenevä grafeeminen tiheys tekee tekstistä jo näönvaraisesti tarkasteltuna kohosteisena hahmoistuvan koosteen. Pieneen tilaan tiiviiksi, sisäisen kronologiansa puitteissa säännönmukaiseksi - toistuvat grafeemit ilmenevät tekstin kaikissa sanoissa samassa järjestyksessä - rykelmäksi pakkautuneet kirjoitusmerkit synnyttävät tyhjän aukeaman alalaitaan poikkeuksellisen tiheänä ja latautuneena mieltyvän tekstuaalisen alueen. 
Semanttisella tasolla kooste hahmottuu metalyyrisenä, sanaruumiiden painoväriin palautuvan intensiivisyyden ja kirjoituksesta tyhjän paperialueen välistä relaatiota kommentoivana tekstinä. Tekstissä semanttisella tasolla ilmaistu tukkoon kukkimisen myöntö tai toive kohdistuu aukeaman tyhjään paperitilaan: sanaruumiskoosteen aineellisia rajoja ympäröivä valkoinen kenttä intensifioituu tekstin vaikutuksesta kielen "kukkimisen" alustaksi, puhkeamaisillaan olevan materiaalisen intensiteetin tilaksi. Metamorfisen sanaruumiskoosteen komponentit hahmottuvat tekstirivillä näin yhtä aikaa sekä materiaalisissa että ilmaisevissa rooleissa. Yhtäällä tekstin ytimessä on sanaruumiista toiseen painojäljen intensiivisyytenä etenevä materiaalinen muutos, toisaalta taas koosteisen kokonaisuuden tyhjää paperitilaa intensifioiva, kieltä kukkimaan kehottava ilmaisevuus. Aukeaman valkoinen, kirjoituksesta tyhä kenttä kytkeytyy näin sanaruumiskoosteeseen itsenäisenä, materiaalisessa roolissa toimivana komponenttina, jonka ruumiillisuus ei ole sanan painovärillistä, vaan ennemminkin paperiarkin kuituista ruumiillisuutta.

Arkin kääntöpuolelta läpi kuultavat, epäselvinä varjomaisina häivähdyksinä aukeamalla ilmenevät (ei-)tekstuaaliset alueet aktualisoivat koosteessa kielen tulemisen prosessia. Runokielen tuleminen hahmoistuu näin paperilla havaittavaksi ja aukeaman ainokaiseen sanaruumiskoosteeseen suhteutuvaksi, mutta samalla jäsentymättömäksi ja keskeneräiseksi epäjärjestyksen alueeksi. Paperin läpi havaittava tuleva kieli on materialisoitumisen ja ruumiillistumisen tilassa, mutta tyhjällä aukeamalla silti pohjimmiltaan yhä ei-aineellista ja ei-ruumiillista; lukija havaitsee kirjan sivulla jotakin, jota tällä nimenomaisella sivulla ei materiaalisesti tarkasteltuna ole kuitenkaan olemassa. Sisäkkäin taiteltujen sivujen laskoksiin painettu kieli on Marjamäen kokoelmassa tulemisen jatkuvaa liikettä, lukutapahtumassa konkretisoituvaa materian intensiivistä ilmenemistä, muuntumista ja hajaantumista. Himmeän, kaoottisen aineen aktualisoituminen sanaruumiilliseksi koosteeksi on teoksessa aina vain sivunkääntämisen tapahtuman päässä.

Painetun kielen aineellisiin ominaisuuksiin palautuva kohosteisuus rakentaa Ei kenenkään laiturin teksteihin ilmaisevuutta, joka ei paikannu saati sitten tyhjene sanojen semanttisten merkitysten alueelle. Uusmaterialistisesta näkökulmasta tarkasteltuna teoksen runokieli kyseenalaistaa näin tekstin merkityssisällön runon ensisijaisena funktiona; sanaruumiskoosteen muodostavien komponenttien semanttinen sisältö on vain yksi osa runokielen ilmaisevuutta, uusia ajatuksia muodostavaa potentiaalia. Kielen materiaalinen toiminta ilmenee Marjamäen kokoelman sivuilla sanojen ruumiillisina kytköksinä, tekstin painojäljen intensiivisyytenä sekä kirjoituksesta tyhjän paperitilan erilaisina jännitteistymisinä. Epätasaisesti tekstiriveille levittynyt painoväri ja sanaruumiiden väliset relaatiot hahmottuvat teksteissä aineellisina, ilmaisevina eroina, lukutapahtumassa aktualisoituvana tulemisen prosessina. 


\section{Viitteet}

${ }^{1}$ Marjamäen teoksen yksittäisiä sivuja ei ole numeroitu, vaan kokonaisuus on järjestetty kymmeneksi roomalaisittain numeroiduksi sikermäksi. Materiaaliselta rakenteeltaan teoksen sikermät hahmottuvat symmetrisinä suhteessa toisiinsa: kukin sikermistä on laajuudeltaan kahdeksan (numeroimatonta) sivua. Sikermien numerointi on toteutettu teoksessa kautta linjan siten, että kunkin sikermän järjestyksessään kuudennella sivulla esiintyy sikermän järjestysnumero gemenamuotoon (esim. ii, vii) materialisoituneina grafeemeina. Sikermien viimeisillä sivuilla järjestysnumero taas esiintyy konventionaalisemmassa versaalimuodossa (esim. II, VII). Noudatan tässä artikkelissa teoksen omaa suurpiirteistä, sikermäperusteista numerointikäytäntöä yksittäisiin teksteihin viitatessani; esimerkiksi teoksen ensimmäiselle sivulle painettu tekstirivi "kielo talvehtii piiloutuneena kieltoon" paikantuu luennassani sikermän i/I osaksi, vaikka kyseisellä sivulla ei ole lainkaan sivunumeroa. Analyysin lomaan oheistamani tekstiesimerkit ovat skannauksia käyttämästäni teoskappaleesta.

${ }^{2}$ Miellän representaation käsitteen tässä yhteydessä kielitieteellisesti; kielen representatiivisuudella tarkoitan kieltä johonkin itsensä ulkopuolella olevaan asiaan viittavana ja siten tätä edustavana (ks. Tieteen termipankki: Kielitiede:representaatio)

${ }^{3}$ Manuel DeLanda $(2002,159)$ on huomioinut Deleuzen käyttävän intensiteetin käsitettä tuotannossaan kolmella eri tavalla. Yhtäällä kyse on termodynaamisiin ilmiöihin viittaavasta käsitteestä: intensiteetti on kohteen ominaisuuksien, kuten paineen tai lämpötilan, eroa. Toiseksi intensiteetti käsitteellistyy Deleuzella koosteen heterogeenisyydeksi: toisistaan eroavat komponentit voivat toisin sanoen koosteistua yhtenäiseksi kokonaisuudeksi ilman, että komponenttien keskinäiset erot homogenisoidaan. Paneudun koosteen käsitteeseen tarkemmin tämän artikkelin luvussa "Intensiiviset sanaruumiskoosteet". Kolmanneksi intensiteetti viittaa Deleuzen ajattelussa erojen peräkkäisyyteen, relationaaliseen sarjoittumiseen, ja tässä sarjoittumisessa ilmeneviin välitiloihin. (Ks. myös Kurikka 2013, 43.) Deleuzen ajattelua edelleen kehittelevä Elisabeth Grosz $(2008,76)$ taas käsitteellistää intensiivisyyden juuri taiteelle ominaiseksi voimaksi: taide tuottaa tai uuttaa (extract) intensiteettiä aistimukselliseen muotoon luonnollisen maailman materiaalisesta kaaoksesta.

${ }^{4}$ Tekstilajien välisten rajojen hämärtyminen on ollut aivan viime vuosina julkaistussa kotimaisessa lyriikassa verrattain yleistä. Raisa Marjamäen lisäksi lajien välisillä rajoilla ovat omissa teoksissaan operoineet muiden muassa Kristian Blomberg, Tiina Lehikoinen, V.S. Luoma-aho ja Olli-Pekka Tennilä. Runon, aforismin, epigrammin ja fragmentin muotokielien välisistä määritelmällisistä eroista ks. Envall 1987, 171-191.

${ }^{5}$ Viimeaikaisessa suomalaisessa lyriikantutkimuksessa kielen materiaalisuutta on tarkasteltu ensisijaisesti suhteessa runon merkityssisältöihin. Topi Lappalainen (2012, 40-42) kirjoittaa Henrika Ringbomin lyriikkaa käsittelevässä artikkelissaan materiaalisuuden poetiikasta, jossa keskeistä on kielen materiaalisuuden kytkös runon metalyyrisyyteen ja sitä kautta merkityssisältöihin. Siru Kainulainen (2012, 62-63) taas tarkastelee omassa, Aila Meriluodon ja Eila Kivikk’ahon runoja käsittelevässä artikkelissaan runon rytmiä elementtinä, joka havainnollistaa kielen materiaalista toimintaa osoittaen, millä tavoin runon kieliaines vaikuttaa ja merkitsee. Oma tulokulmani Ei kenenkään laiturin teksteihin poikkeaa Lappalaisen ja Kainulaisen analyyttisista lähtökohdista siinä, että en luennassani suhteuta kielen materiaalista, immanenttia toimintaa kirjan sivulla ensisijaisesti runouden sisältöihin tai merkityksiin. 
Analyysini fokus on tekstin materiaalisen toiminnan ja relaatioiden sekä näiden synnyttämien vaikutusten tarkastelussa.

${ }^{6}$ Ajatus runoudesta vaikutuksia tuottavana materiaalisena kielenä sivuaa likeisesti kysymystä runon affektiivisuudesta, johon ei tämän artikkelin materiaalisissa rajoissa ole kuitenkaan mahdollista paneutua sen tarkemmin. Miellän runo(kiele)n affektiivisuuden tässä yhteydessä Jon Clayn $(2010,64)$ tavoin ei-persoonalliseksi ja ei-inhimilliseksi, lukijan ja tekstin välisessä vuorovaikutuksessa aktualisoituvaksi ja lukijaan konkreettisesti vaikuttavaksi voimaksi.

${ }^{7}$ Selvyyden vuoksi lienee hyvä huomauttaa, että sanan ruumiillinen materiaalisuus ja sanaruumiskoosteen komponentin materiaalinen rooli ovat eri asioita; edellinen viittaa paperille painetun sanan immanenttiin, välttämättömään ominaisuuteen, kun taas jälkimmäinen kytkeytyy koosteen relationaaliseen rakentumiseen. Toisin sanoen sama komponentti - esimerkiksi sanaruumis 'kielo' - voi saada erilaisia materiaalisia ja/tai ilmaisevia rooleja suhteessa koosteen muihin komponentteihin (ks. DeLanda 2006, 12).

${ }^{8}$ Teoksen painoteknisistä ratkaisuista johtuva painovärin epätasainen levittyminen kirjan sivulle ilmenee kokoelman sisäisen intensiivisyyden ohella myös teoskappaleiden tasolla. Jo pintapuolinen vertailu useamman eri teoskappaleen välillä osoittaa, että painojälki vaihtelee kappaleesta toiseen huomattavissa määrin. Toisin sanoen jokainen Marjamäen kokoelman teoskappale on materiaalisesti tarkasteltuna partikulaarinen olio. Näin ollen tässä artikkelissa tekemäni luennat ovat pitäviä vain käyttämäni teoskappaleen (nro 40) osalta.

${ }^{9}$ Runossa on yhteensä, yksinäinen pilkku mukaan luettuna, 40 kirjoitusmerkkiä. Näistä 12 on joko $o$ - tai $a$-kirjaimia. Teos on painettu fontilla, joka materialisoi pienet $a$ - ja $o$-kirjaimet kirjan sivulle sangen samannäköisiksi grafeemeiksi. Pieni $a$-kirjain ilmenee kokoelmassa kautta linjan ilman monia kirjasinlajeja määrittävää grafeemin yläruumiin kaarevaa väkästä; $a$-kirjain mieltyy täten kuin hieman kulmikkaampana $o$-kirjaimena, kun taas kääntäen ilmaistuna $o$ on kuin ympyränmuotoinen $a$.

${ }^{10}$ Daniel W. Smith (1997, xxx) käsitteellistää tulemisen minkä tahansa kahden olion tässä tapauksessa siis lukijan ja tekstin - välillä vaikuttavaksi, eron tuottumista välittömästi edeltäväksi huomaamattomaksi tai epäselväksi alueeksi, olioiden transformatiivisen relaation rajatilaksi.

${ }^{11}$ Miellän pakoviivan tässä yhteydessä Tamsin Lorrainen $(2010,147)$ tavoin ruumiillisten olioiden välillä aktualisoituvaksi kytkeytymiseksi, muutoksen poluksi (path of mutation).

\section{Lähteet}

\section{Primäärilähteet}

Marjamäki, Raisa 2014. Ei kenenkään laituri [= EKL]. Helsinki: Poesia.

\section{Sekundäärilähteet}

Baugh, Bruce 2000. How Deleuze Can Help Us Make Literature Work. Ian Buchanan \& John Marks (eds), Deleuze and Literature. Edinburgh: Edinburgh University Press, 34-55.

Baugh, Bruce 2010 (2005). Body. Adrian Parr (ed.), The Deleuze Dictionary: Revised Edition. Edinburgh: Edinburgh University Press, 35-37. 
Clay, Jon 2010. Sensation, Contemporary Poetry and Deleuze. London \& New York: Continuum.

Colebrook, Claire 2010 (2005). Expression. Adrian Parr (ed.), The Deleuze Dictionary: Revised Edition. Edinburgh: Edinburgh University Press, 95-97.

Connolly, William 2011. A World of Becoming. Durham \& London: Duke University Press.

Coole, Diana \& Samantha Frost 2010. Introducing the New Materialisms. Diane Coole \& Samantha Frost (eds), New Materialisms: Ontology, Agency, and Politics. Durham \& London: Duke University Press, 1-43.

DeLanda, Manuel 2002. Intensive Science and Virtual Philosophy. London \& New York: Continuum.

DeLanda, Manuel 2006. A New Philosophy of Society. Assemblage Theory and Social Complexity. London: Bloomsbury.

Deleuze, Gilles 1994. Difference and Repetition. (Différence et Repetition, 1968.) Transl. Paul Patton. New York: Columbia Univeristy Press.

Envall, Markku 1987. Suomalainen aforismi. Keinoja / rakenteita / lajeja / ongelmia. Helsinki: SKS.

Grosz, Elisabeth 2008. Chaos, Territory, Art: Deleuze and the Framing of the Earth. New York: Columbia University Press.

Hertzberg, Fredrik 2002. Moving Materialities: On Poetic Materiality and Translation with Special Reference to Gunnar Björling's Poetry. Åbo: Åbo Akademi University Press.

Huth, Geof 2010. Silmän ensisijaisuudesta ja muita ajatuksia visuaalisen runouden arvottamisesta. TuliఠSavu 18.9.2010. http://www.tulijasavu.net/2010/09/ silman-ensisijaisuudestal (2.9.2015).

Joensuu, Juri 2012. Menetelmät, kokeet, koneet. Proseduraalisuus poetiikassa, kirjallisuushistoriassa ja suomalaisessa kokeellisessa kirjallisuudessa. Helsinki: Poesia.

Kainulainen, Siru 2011. Kun sanat eivät riitä. Rytmi, modernismi ja Eila Kivikk'ahon runous. Turku: Turun yliopisto.

Kainulainen, Siru 2012. Tanssivat räjähdykset, säilymättömyyden pyörre: rytmin liikettä 1960-luvulla. Siru Kainulainen, Karoliina Lummaa \& Katja Seutu (toim.), Työmaana runous. Runoudentutkimuksen nykysuuntauksia. Helsinki: SKS, 61-83.

Kainulainen, Siru, Karoliina Lummaa \& Katja Seutu 2012. Lukijalle. Siru Kainulainen, Karoliina Lummaa \& Katja Seutu (toim.), Työmaana runous. Runoudentutkimuksen nykysuuntauksia. Helsinki: SKS, 7-12.

Katajamäki, Sakari 2004. "Kukunor, - Niin kaunis sana!" Metakielellisyys Lauri Viidan Kukunorissa. Katriina Kajannes, Leena Kirstinä \& Annika Waenerberg (toim.), Katkos ja kytkös. Modernismin ja postmodernismin subde traditioon. Helsinki: SKS, 136-161. 
Kurikka, Kaisa 2013. Algot Untola ja kirjoittava kone. Turku: Eetos.

Lappalainen, Topi 2012. Materiaalisuus ja merkitys. Henrika Ringbomin 1990-luvun runoudesta. Siru Kainulainen, Karoliina Lummaa \& Katja Seutu (toim.), Työmaana runous. Runoudentutkimuksen nykysuuntauksia. Helsinki: SKS, 40-60.

Lorraine, Tamsin 2010 (2005). Lines of Flight. Adrian Parr (ed.), The Deleuze Dictionary: Revised Edition. Edinburgh: Edinburgh University Press, 95-97.

Smith, Daniel W. 1997. Introduction. "A Life of Pure Immanence": Deleuze's "Critique et Clinique" Project. Gilles Deleuze, Essays Critical and Clinical. (Critique et Clinique, 1993.) Transl. Daniel W. Smith \& Michael Greco. Minneapolis: University of Minnesota Press, xi-lvi.

Stagoll, Cliff 2010 (2005). Becoming. Adrian Parr (ed.), The Deleuze Dictionary: Revised Edition. Edinburgh: Edinburgh University Press, 25-27.

Tiainen, Milla \& Parikka, Jussi 2010. What is New Materialism - Opening words from the event. Machinology 23.6.2010. http://machinology.blogspot.fi/2010/06/ what-is-new-materialism-opening-words.html (6.2.2015).

Tieteen termipankki. Kielitiede:kielto. http://www.tieteentermipankki.fi/wiki/ Kielitiede:kielto (1.3.2015).

Tieteen termipankki. Kielitiede:representaatio. http://www.tieteentermipankki.fi/wiki/ Kielitiede:representaatio (19.2.2015). 